\title{
MENINGKATKAN KESADARAN MASYARAKAT DALAM MENJAGA KEBERSIHAN LINGKUNGAN SEBAGAI UPAYA PENCEGAHAN PENYEBARAN COVID-19 DI DESA KUBUR TELU
}

\author{
Farhana Muhammad ${ }^{1)}$, Huzain Jailani' ${ }^{1)}$, Isfi Sholihah ${ }^{1)}$ Danang Prio Utomo') \\ 1)Program Srudi Pendidikan Ekonomi, FISE, Universitas Hamzanwadi, Selong, NTB, Indonesia \\ Corresponding author :Farhana Muhammad \\ E-mail : farhana.fm88@gmail.com
}

Diterima 08 November 2020, Direvisi 19 November 2020, Disetujui 19 November 2020

\begin{abstract}
ABSTRAK
Coronavirus disease-2019 atau yang lebih dikenal dengan Covid-19 merupakan virus yang menyerang sistem pernapasan manusia yang dapat menyebabkan infeksi saluran pernapasan manusia, batuk pilek hingga yang lebih serius adalah seperti Middle East Repiratory Syndrome (MERS) dan Severe Acute Respiratoey Syndrome (SARS). Penyebaran COVID 19 semakin meningkat dan semakin masif sehingga perlu dilakukan pencegahan sejak dini salah satunya dengan menjaga pola hidup sehat dan bersih. Pola hidup sehat dan bersih sangat penting untuk ditingkatkan, pola hidup sehat salah satunya dapat dimulai dari menjaga kebersihan lingkungan,akan tetapi di RT Kubur Telu kesadaran masyarakat dalam menjaga kebersihan lingkungan masih minim. Oleh karena itu perlu adanya penggerak yang dapat memotivasi masyarakat dan menjadi contoh bagi masyarakat guna menciptakan lingkungan yang bersih, nyaman dan aman. Berdasarkan permasalah tersebut tim melakukan pengabdian kepada masyarakat melalui kegiatan PPM. Tujuan dari PPM ini adalah untuk meningkatkan kesadaran masyarakat hidup sehat dengan melaksanakan protokol kesehatan. Kerjasama kemitraan merupakan metode yang sesuai untuk menjalin kerjasama dengan masyarakat Kubur Telu. Dengan diadakan edukasi dan pembiasaaan protokol kesehatan daam PPM ini didapatkan kesadaran masyarakat dalam menjaga kesebersihan dan kesehatan meningkat
\end{abstract}

Kata kunci: covid-19; kebersihan lingkungan

\begin{abstract}
Coronavirus disease-2019 or better known as Covid-19 is a virus that attacks the human respiratory system that can cause human respiratory tract infections, coughs and colds to more serious ones such as Middle East Repiratory Syndrome (MERS) and Severe Acute Respiratory Syndrome (SARS) . The spread of COVID 19 is increasing and getting more massive so it is necessary to do prevention from an early age, one of which is by maintaining a healthy and clean lifestyle. A healthy and clean lifestyle is very important to be improved, a healthy lifestyle, one of which can be started from maintaining a clean environment, but in RT Kubur Telu, public awareness in maintaining environmental cleanliness is still minimal. Therefore, it is necessary to have an activator who can motivate the community and become an example for the community to create a clean, comfortable and safe environment. Based on these problems, the team provides community service through PPM activities. The purpose of this PPM is to increase public awareness of healthy living by implementing health protocols. Partnership cooperation is an appropriate method for cooperating with the Kubur Telu community. By holding education and familiarity with health protocols in this PPM, public awareness in maintaining hygiene and health increases.
\end{abstract}

Keywords: covid-19; environmental cleanliness

\section{PENDAHULUAN}

Coronavirus adalah zoonosis atau virus yang ditularkan antara hewan dan manusia. Penyebaran penyakit ini telah memberikan dampak luas secara sosial dan ekonomi. Coronavirus-19 (COVID) telah dinyatakan sebagai pandemi dunia oleh WHO. Penyakit Korona 2019 atau yang lebih sering kita dengar sebagai Coronavirus Disesase 2019 COVID 19, adalah penyakit jenis baru yang belum pernah di identifikasi sebelumnya oleh manusia dengan gejala umum infeksi seperti gejala gangguan pernapasan akut seperti demam, batuk, dan sesak napas. (Dewi, 2020). Virus Corona atau disebut pula Covid19 (Corona Virus Disease 2019) ditemukan pertama kali di Kota Wuhan, China pada akhir Desember 2019 (Yunus \& Rezki, 2020). Pada jangka waktu yang relatif 
singkat, virus ini dengan sangat cepat telah menyebar ke hampir seluruh negara di dunia, termasuk Indonesia. Sejumlah pengamat mengkategorikan Covid-19 sebagai salah satu jenis virus yang sangat berbaya dan mematikan. Orang yang terinfeksi virus Covid-19 ditandai akan mengalami gejala flu yang disertai demam, pilek, batuk kering, sakit tenggorokan, dan sakit kepala (Yuliana, 2020).

Penyakit covid-19 dapat menginfeksi tanpa memberikan gejala klinis, sehingga penderita tidak merasakan perubahan dalam dirinya. Beberapa gejala klinis yang dirasakan mulai dari flu biasa, batuk dan pilek. Gejala klinis yang lebih berat seperti demam tinggi, nyeri tenggorokan, nyeri otot, kehilangan indra pembau dan perasa, sesak nafas hingga menyebabkan kematian (Huang et al., 2020).

Pandemi mengharuskan pentingnya memutus rantai transmisi dan melindungi populasi dari risiko (Zhang, Zhao, \& Hu, 2020). Pemutusan rantai penularan virus bisa dilakukan secara individu dengan melakukan kebersihan diri terutama cuci tangan dan secara kelompok dengan cara social distancing(Zhai et al., 2020). Social distancing adalah praktik dengan cara memperlebar jarak antar orang sebagai upaya menurunkan peluang penularan penyakit (SenCrowe, McKenney, \& Elkbuli, 2020).

Upaya pemerintah dalam menekan penyebaran virus corona terus dilakukan secara masif hampir disemua aspek kehidupan .Dibidang pendiidikan pemerintah menerapkan program belajar di rumah.. Dibidang sosial masyarakat, pemerintah telah menjalankan program sosial distancing yang merupakan pembatasan sosial , physical distancing yaitu menjaga jarak dengan orang lain minimal 1 meter. Dibidang kesehatan, pemerintah telah gencarnya menyerukan kepada masyarakat agar menerapkan pola hidup sehat dan hidup bersih dari berbagai media seperti perlunya menggunakan masker saat diluar ruangan, karantina mandiri bagi orang-orang yang memiliki resiko tinggi terrinfeksi serta berbagai pedoman yang bertujuan untuk mencegah penularan Covid-19. Pemerintah kabupaten Lombok timur tidak luput dari upaya penyebaran Covid-19, pemkab lotim menyiapkan rumah sakit rujukan bagi paien terinfeksi Covid-19 untuk mempercepat penanganan covi-19, rumah sakit tersebut juga dijadikan sebagai tempat karantina bagi Orang Dalam Pemantauan (ODP) dan Pasien Dalam Pengawasan (PDP). Selain itu, pemerintah desa juga menyiapkan rumah isolasi disetiap dusun untuk mengisolasi warga yang memiliki resiko tinggi terinfeksi virus corona seperti masyarakat yang baru pulang merantau.
Kubur telu merupakan salah satu dari banyaknya RT yang ada di Kecamatan Selong Lombok Timur, RT ini merupakan tempat tinggal yang cukup padat dan berada dipinggir sawah, namun kesadaran masyarakat dalam menjalankan pola hidup sehat dan bersih serta menerapkan protokol kesehatan masih minim, hal ini membuat masyarakat rentan terhadap penyebaran Covid-19.Dengan melihat situasi masyarakat di Kubur Telu, kami melakukan pengabdian kepada masyarakat melalui program Kuliah Kerja Nyata Fase New Normal dengan melakukan kontribusi dalam penanggulangan penyebaran Covid-19 melalui upaya pencegahan yang efektif.

Berdasarkan latar belakang masalah tersebut pengabdi berinsiatif untuk menjalankan serangkaian program yang diberi nama GEMS (Gerakan Edukasi Masyarakat Sehat) yang salah satu kegiatannya adalah bersih-bersih lingkungan dengan bantuan mahasiswamahasiswi Universitas Hamzanwadi. Hal ini bertujuan untuk memotivasi masyarakat untuk tetap menjaga kebersihan lingkungan serta menyadari pentingnya menjaga kebersihan lingkungan guna menciptakan lingkungan yang nyaman, bersih dan aman

\section{METODE}

Pengabdian kepada masyarakat melalui program PPM Universitas Hamzanwadi Fase New Normal ini dilaksanakan di Kubur Telu RT 05 Kec. Selong Kabupaten Lombok Timur. Untuk mencapai tujuan yang diharapkan PPM Universitas Hamzanwadi menggunakan metode pendekatan kerjasama kemitraan dengan tahapan (1) persiapan kegiatan pengabdian; (2) kegiatan pembersihan lingkungan.

\footnotetext{
Persiapan

Merupakan koordinasi dengan mitra dalam hal ini pihak perangkat lingkungan seperti Lurah, Kapling, dan RT dalam rangka menyampaikan program serta pelaksanaan program yang telah dirancang untuk direalisasikan di Kubur Telu RT 05. Adapun diskusi hal lainnya yang dibahas adalah peralatan yang dapat menunjang kegiatan, serta titik strategis yang menjadi sasaran kegiatan sehingga berlangsung dengan tertib dan berjalan sebagaimana harapan. Serta persiapan jadwal yang disepakati kegiatan bersih lingkungan dilaksanakan satu kali dalam seminggu yaitu pada hari Jum'at. Adapun target dalam kegiatan ini adalah seratus responden yang mendapatkan edukasi hidup sehat.
} 


\section{Pelaksanaan Kegiatan}

Pelaksanaan kegiatan bersih lingkungan dilaksanakan setiap hari Jum'at Pukul 07.30 WITA oleh tim PPM Universitas Hamzanwadi, pemuda serta masyarakat yang sukarela membantu. Adapun pelaksanaan kegiatan ini tetap mengikuti protokol kesehatan seperti memakai face shield dan masker.

Adapun tim dalam pengabdian ini daqpat dilihat pada Tabel 1 berikut :

Tabel 1. Tim dalam pengabdian.

\begin{tabular}{|c|c|c|c|}
\hline $\begin{array}{l}\mathrm{N} \\
\mathrm{O}\end{array}$ & Tim & Pelaksana & NIDN \\
\hline 1 & $\begin{array}{l}\text { Persiapan } \\
\text { strategi } \\
\text { Pengabdia } \\
\mathrm{n}\end{array}$ & $\begin{array}{ll}\text { Susilawati } & \text { S.Pd., } \\
\text { ME } & \\
\text { Drs. } & \text { Agus } \\
\text { Riswanto, M.Pd }\end{array}$ & $\begin{array}{l}0813028 \\
605 \\
0822046 \\
501 \\
\end{array}$ \\
\hline 2 & $\begin{array}{l}\text { Pengemba } \\
\text { ng dan } \\
\text { pelaksana }\end{array}$ & $\begin{array}{l}\text { Huzain Jailani } \\
\text { M.Pd } \\
\text { Isfi Sholihah M.SI } \\
\text { Dr. Muhamad Ali } \\
\text { M.Si } \\
\text { Farhana } \\
\text { Muhammad S.Pd., } \\
\text { ME } \\
\text { Tim Mahasiswa } \\
\text { HMPS Prodi } \\
\text { Ekonomi }\end{array}$ & $\begin{array}{l}0828028 \\
802 \\
0819128 \\
404 \\
0831127 \\
801 \\
0825078 \\
803\end{array}$ \\
\hline 3 & Kordinasi & $\begin{array}{l}\text { Danang } \\
\text { Utomo MM }\end{array}$ & $\begin{array}{l}0825038 \\
304 \\
\end{array}$ \\
\hline
\end{tabular}

\section{HASIL DAN PEMBAHASAN}

Hasil

Berdasarkan hasil observasi yang telah dilakukan, kesadaran masyarakat di Kubur Telu dalam menjaga kebersihan lingkungan masih kurang hal ini dapat dilihat dari masih banyaknya masyarakat yang membuang sampah sembarangan, selain karena faktor kesadaran yang masih minim hal ini juga dipengaruhi oleh faktor tempat tinggal yang berada dipedalaman, sehingga kebiasaan membuang sampah merupakan hal yang lumrah. Oleh karena itu mahasiswa PPM berinisiatif untuk melaksanakan program Gerakan Edukasi Masyarakat Sehat (GEMS) yang didalamnya terdapat kegiatan bersihbsersih lingkungan setiap hari Jum'at yang bekerja sama dengan pemuda/i Kubur Telu.Program ini berhasil dalam meningkatkan motivasi dan kesadaran masyarakat Kubur Telu dalam menjaga kebersihan lingkungan. Hal ini dapat dilihat dari partisipasi masyarakat untuk membersihkan lingkungan tempat tinggal mereka dan kebiasaan membuang sampah sembarangan cukup berkurang.

\section{Pembahasan}

Kebersihan lingkungan adalah keadaan bebas dari kotoran yang termasuk diantaranya debu, sampah dan bau. seperti dalam penelitian Lois Pastuer yang menemukan bahwa proses penularan penyakit atau infeksi disebabkan oleh mikroba, kebersihan juga diartikan bebas dari virus, bakteri patogen, dan bahan kimia yang berbahaya. Masyarakat sudah barang tentu sangat perlu menjaga kebersihan lingkungan terlebih keadaan saat ini yang dapat dikatakan rentan terhadap penyebaran virus Covid-19.

Covid-19 merupakan virus yang menyerang sistem pernapasan manusia yang dapat mengakibatkan penderitanya mengalami gangguan pernapasan, demam, pilek bahkan kematian.Penularan Covid-19 begitu cepat sehingga organisasi kesehatan dunia (WHO) menetapkan virus corona sebagai pandemi. Status pandemi atau epidemi global menandakan bahwa penyebaran Covid-19 berlangsung sangat cepat hingga hampirtak ada negara di dunia yang dapat memastikan diri terhindar dari virus corona (Widiyani dalam 2020) dalam upaya menekan penyebaran virus corona dengan menumbuhkan kesadaran masyarakat terhadap pentingnya hidup bersih, mahasiswa PPM Universitas Hamzanwadi bekerja sama dengan Pemuda/i Kubur Telu dalam menjalankan program bersih-bersih lingkungan dan penyemprotan disinfektan.

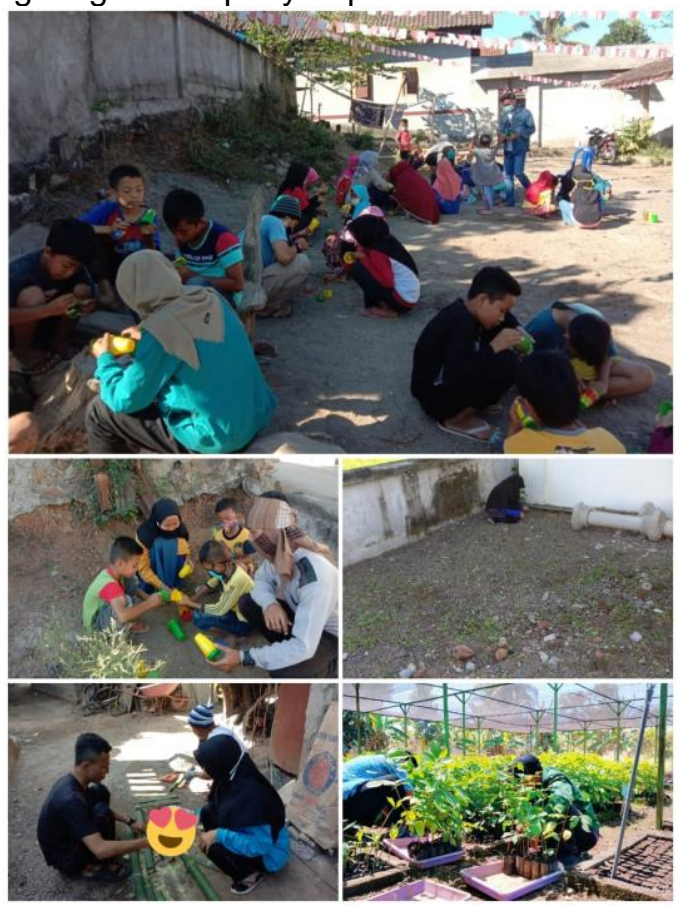

Gambar 1. Kegiatan Pengabdian (Sumber : Dokumentasi kegiatan PPM Kubur Telu). 


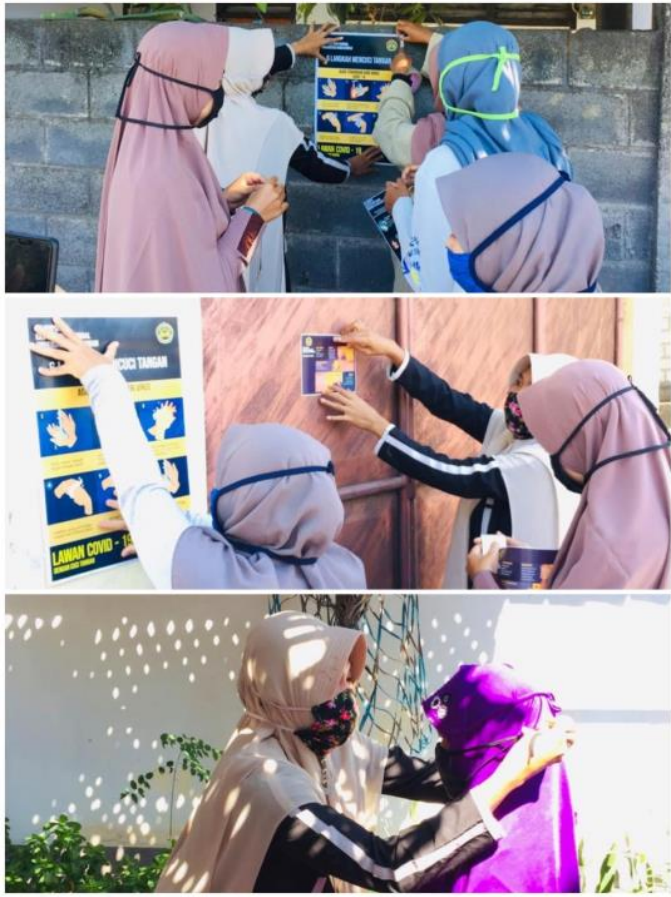

Gambar 2. Kegiatan Pengabdian (Sumber :

Dokumentasi kegiatan PPM Kubur Telu).

\section{SIMPULAN DAN SARAN}

Berdasarkan pembahasan yang sudah tertera di atas, dapat di simpulkan bahwa program PPM Universitas Hamzanwadi dalam mejaga kebersihan lingkungan di Kubur Telu telah berjalan dengan baik, hal ini dapat di lihat dari respon positif. Masyarakat Kubur Telu yang ditunjukkan dengan kontribusi serta partisipasi aktif dalam kegiatan bersih-bersih lingkungan sehingga Kubur Telu kedepannya tetap istiqamah dalam menjaga kebersihan lingkungan

\section{UCAPAN TERIMAKASIH}

Ucapan terimakasih kami sampaikan kepada semua pihak yang terlibat baik manajemen kampus rektor, dekan dan korprodi serta teman dosen dan mahasiswa, terimakasih juga kami ucapkan kepada pihad desa yang ikut terlibat kepala desa, kadus, dan RT yang telah memberikan kesempatan untuk melakukan pengabdian kepada masyarakat di desa kubur telu.

\section{DAFTAR RUJUKAN}

Dewi, W. A. F. (2020). Dampak Covid-19 terhadap implementasi pembelajaran daring di Sekolah Dasar. Edukatif: Jurnal Ilmu Pendidikan, 2(1), 55-61.

Huang, C., Wang, Y., Li, X., Ren, L., Zhao, J., $\mathrm{Hu}, \mathrm{Y} ., \ldots \mathrm{Gu}, \mathrm{X}$. (2020). Clinical features of patients infected with 2019 novel coronavirus in Wuhan, China. The Lancet, 395(10223), 497-506.

Sen-Crowe, B., McKenney, M., \& Elkbuli, A.
(2020). Social distancing during the COVID-19 pandemic: Staying home save lives. The American Journal of Emergency Medicine.

Yuliana, Y. (2020). Corona virus diseases (Covid-19): Sebuah tinjauan literatur. Wellness And Healthy Magazine, 2(1), 187-192.

Yunus, N. R., \& Rezki, A. (2020). Kebijakan Pemberlakuan Lock Down Sebagai Antisipasi Penyebaran Corona Virus Covid-19. Salam: Jurnal Sosial Dan Budaya Syar-I, 7(3), 227-238.

Zhai, Z., Li, C., Chen, Y., Gerotziafas, G., Zhang, Z., Wan, J., ... Wang, C. (2020). Prevention and treatment of venous thromboembolism associated with coronavirus disease 2019 infection: a consensus statement before guidelines. Thrombosis and Haemostasis, 120(6), 937.

Zhang, Y., Zhao, Q., \& Hu, B. (2020). Community-based prevention and control of COVID-19: Experience from China. American Journal of Infection Control, 48(6), 716-717. 